This item was submitted to Loughborough's Research Repository by the author.

Items in Figshare are protected by copyright, with all rights reserved, unless otherwise indicated.

\title{
Comparing the minimum income standard in the UK and Japan: methodology and outcome
}

\section{PLEASE CITE THE PUBLISHED VERSION}

http://dx.doi.org/10.1017/S147474641300033X

\section{PUBLISHER}

(c) Cambridge University Press

\section{VERSION}

VoR (Version of Record)

\section{PUBLISHER STATEMENT}

This work is made available according to the conditions of the Creative Commons Attribution-NonCommercialNoDerivatives 4.0 International (CC BY-NC-ND 4.0) licence. Full details of this licence are available at: https://creativecommons.org/licenses/by-nc-nd/4.0/

\section{LICENCE}

CC BY-NC-ND 4.0

\section{REPOSITORY RECORD}

Davis, Abigail, Donald Hirsch, Rie Iwanaga, Masami Iwata, Junko Shigekawa, Yuka Uzuki, and Atsuhiro Yamada. 2019. "Comparing the Minimum Income Standard in the UK and Japan: Methodology and Outcome". figshare. https://hdl.handle.net/2134/13265. 


\section{Social Policy and Society}

http://journals.cambridge.org/SPS

Additional services for Social Policy and Society:

Email alerts: Click here

Subscriptions: $\underline{\text { Click here }}$

Commercial reprints: Click here

Terms of use : $\underline{\text { Click here }}$

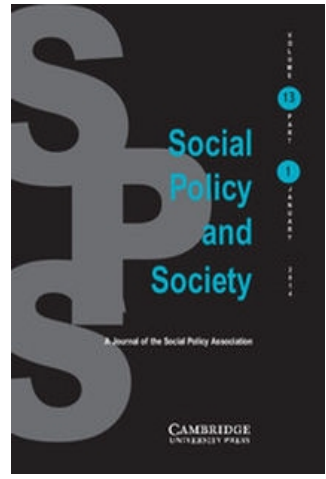

\section{Comparing the Minimum Income Standard in the UK and Japan: Methodology and Outcome}

Abigail Davis, Donald Hirsch, Rie Iwanaga, Masami Iwata, Junko Shigekawa, Yuka Uzuki and Atsuhiro Yamada

Social Policy and Society / Volume 13 / Issue 01 / January 2014, pp 89 - 101

DOI: $10.1017 / S 147474641300033 X$, Published online: 30 July 2013

Link to this article: http://journals.cambridge.org/abstract S147474641300033X

How to cite this article:

Abigail Davis, Donald Hirsch, Rie Iwanaga, Masami Iwata, Junko Shigekawa, Yuka Uzuki and Atsuhiro Yamada (2014). Comparing the Minimum Income Standard in the UK and Japan:

Methodology and Outcome. Social Policy and Society, 13, pp 89-101 doi:10.1017/

S147474641300033X

Request Permissions : $\underline{\text { Click here }}$ 


\title{
Comparing the Minimum Income Standard in the UK and Japan: Methodology and Outcome
}

\author{
Abigail Davis*, Donald Hirsch**, Rie Iwanaga***, Masami Iwata****, \\ Junko Shigekawa ${ }^{\dagger}$, Yuka Uzuki ${ }^{\dagger \dagger}$ and Atsuhiro Yamada ${ }^{\ddagger}$ \\ * Centre for Research in Social Policy, Loughborough University \\ E-mail: A.A.I.Davis@lboro.ac.uk \\ **Centre for Research in Social Policy, Loughborough University \\ E-mail: D.B.Hirsch@lboro.ac.uk \\ ***School of Social Work, Kanagawa University of Human Services, \\ E-mail: iwanaga-r@kuhs.ac.jp \\ **** Faculty of Integrated Arts and Social Sciences, Japan Women's University \\ E-mail: miwata@fc.jwu.ac.jp \\ $\dagger$ Faculty of Education, Saitama University \\ E-mail: jshigeka@mail.saitama-u.ac.jp \\ $\dagger \dagger$ Department for International Research and Co-operation, National Institute for Educational Policy Research \\ E-mail: yuzuki@nier.go.jp \\ $\ddagger$ Faculty of Economics, Keio University \\ E-mail: atsuhiro@econ.keio.ac.jp
}

Minimum Income Standard (MIS) research involves an innovative methodology that combines consensual decisions made through discussion by members of the public, supported by input from experts. MIS addresses questions about income adequacy, and in particular, what is the income that people need in order to reach a minimum socially acceptable standard of living. The first MIS for Britain was published in the UK in 2008, and in 2010 researchers from Japan and the UK began to collaborate on developing a comparable Minimum Income Standard for Japan. This article discusses the differences and similarities between the UK and Japanese MIS. It looks at the challenges of applying the methodology in a very different setting and compares the results of the research in the UK and in Japan. Although there are notable differences in the lists of goods and services that comprise the budgets, there are also some striking similarities. This research suggests that the MIS methodology offers an approach that can be used in different countries to inform discussions on contemporary living standards and societal norms, and to enable international comparisons to be drawn.

Keywords: Minimum income standards, budget standards, Japan, UK.

\section{Introduction}

This article is the result of collaboration between researchers from the UK Minimum Income Standards (MIS) programme and a team of academic researchers in Japan engaged in developing a MIS for Japan. It makes some observations about the experience of using the same methodological structure in two very different places and presents selected 
findings from both projects. It goes on to discuss how this approach can contribute to knowledge about public perceptions of minimum living standards and outlines the scope for further international comparisons in the future.

\section{Background}

The MIS programme of research began in the UK in 2006 when the Family Budget Unit (FBU), based at the University of York collaborated on a joint project with the Centre for Research in Social Policy (CRSP) at Loughborough University. This study was designed to harness the strength of two different approaches to budget standards - a consensual approach that had been developed by CRSP (Middleton et al., 1994; Middleton, 1997, 2000; Walker, 1987) and the survey-data based and expert-led FBU method, which had previously been used to develop detailed budget standards (Parker, 1995, 1998).

The first Minimum Income Standard for Britain (Bradshaw et al., 2008) was published in 2008, with further work being conducted in Northern Ireland (Smith et al., 2009) and additional research on rural budgets (Smith et al., 2010) combining to create a Minimum Income Standard for the UK in 2010 (Davis et al., 2010).

In 2010, collaboration began with a team of researchers in Japan to find the income needed in order for different households to have a minimum socially acceptable standard of living, using an adapted version of the UK MIS methodology.

This project was a result of the formation of the Research Committee on a National Minimum, instigated by the then Minister of Health, Labour and Welfare, Akira Nagatsuma. The committee was inaugurated in response to a perceived need to review a national minimum guaranteed income in a multifaceted manner. ${ }^{1}$ To put it in a broader context, the Japanese MIS project responds to a more general demand to revive studies on the minimum cost of living as a basis for developing the structure of a Japanese welfare state for the twenty-first century (Iwanaga and Iwata, 2012).

As a part of this project, the Japan team calculated the minimum income standard for single working-age adults and single pensioners in Mitaka, a residential city with a population of 180,000 located in western Tokyo, in 2010 and 2011 respectively. While the Japan team followed the broad framework of the MIS method developed in the UK, it made some modifications where the implementation of the original method in its entirety proved difficult given the Japanese context.

However, it is important to note two essential principles that were followed in the Japanese research that make the measure comparable to that applied in the UK, whose main methodological principles are set out in Bradshaw et al. (2008: 6-12). The first is that decision-making about which items to include in household budgets are governed by the collective judgement of the groups: the budgets therefore represent a negotiated social consensus rather than an expert judgement. The second is that the groups comprise a cross-section of citizens specifying a common minimum that anyone in society requires. This differs from some consensual budget methods applied in other countries, which ask only a subset of citizens (such as people on low incomes) to specify necessities, and/or use concepts such as 'poverty' in a way that suggests that the minimum applies only to the needs of a subset of the population (see, for example, Nibud, 2010). 


\section{Defining a socially acceptable minimum}

The MIS approach involves a series of groups of members of the public reaching consensus, through detailed discussion, on the goods and services needed in order to provide the standard of living outlined in the definition. These decisions are translated into detailed lists of items and costs, supported by expert input on nutrition, fuel consumption and (since 2012) transport. In order to develop these lists, participants are asked to decide on everything needed by a hypothetical 'case study' individual, such that they would be able to have a standard of living outlined in the following statement:

A minimum standard of living in the UK today includes, but is more than, just food, clothes and shelter. It is about having what you need in order to have the opportunities and choices necessary to participate in society.

This definition was derived from thematic analysis of focus group discussions held in 2006 to explore what elements participants thought a minimum living standard needed to include. It has been used in all subsequent MIS work in the UK, as well as in Guernsey.

The research team in Japan held a similar group discussion in order to develop an equivalent statement that had meaning and relevance for participants there. The definition used in the Japanese project was:

In contemporary Japan, the basic standard of living required for everyone as a minimum means having a sanitary and healthy way of living backed by a sense of security and stability. It includes not only clothing, food and accommodation, but also an environment where necessary information, relationships, entertainment, appropriate ways of working, education and solid future prospects are available.

It can be seen that both elements share an acknowledgement that the socially acceptable minimum should not provide merely the means for survival, but also include an element of social participation. Importantly, the fact that two different countries adopt somewhat different definitions of the minimum does not undermine comparability in MIS terms. On the contrary, it emphasises that in different cultural settings the level of the minimum must be derived using non-identical criteria. The key commonality is that in both cases the definition was based on detailed discussions with members of the public, and so reflects the same underlying method. MIS is not designed to produce an international standard, but does allow comparison of incomes in different countries relative to each country's own minimum standards.

\section{Cultural differences}

The MIS method is designed to identify a case study individual's needs that are unconstrained by income, and to acknowledge that people have different preferences so may choose to use their resources differently than is described within the budgets. The Japanese facilitators found that groups struggled to distance their own experiences of constraints and preferences, which made finding consensus within some budget areas quite difficult. 
In particular, it took time to reach an agreement on social and cultural participation. There was much discussion of lifelong learning, which was viewed as an expensive activity. Groups at the first and second stages discussed this but could not reach consensus. However, the issue was taken to a final negotiation group, where participants eventually agreed that it should be included in the budgets in order to meet the standard of living described in the definition (Shigekawa and Yamada, 2012).

It is interesting to see the cultural differences this debate indicated. In the UK, evening classes were occasionally mentioned as a possible way of fulfilling a need to socialise and interact with others, but more common examples were taking part in sports, attending exercise classes or going to the pub or cinema. However, in Japan, where lifelong learning was considered an important part of education reform in the 1990s (Hirsch, 1993) and became a key part of the policy agenda in 2006 (Ogawa, 2009), the need for continuing access to learning was acknowledged as necessary for all because it was seen as a means of securing future prospects.

The MIS case studies deliberately do not include the employment status of the individual under discussion, and groups are purposively recruited to include a mix of employed and unemployed people. In the UK, where the unemployment rate is higher (8.3 per cent in $2011,{ }^{2}$ compared with 4.5 per cent in Japan), it was easier to recruit participants who were unemployed or worked part-time. However, in Japan the single working-age adults, both men and women, who took part in the group discussions, were all employed, and they expressed feelings that their life revolved around work and commuting on weekdays. This may have affected how well groups were able to think about what might have been needed by someone who was either not working or working fewer hours (Shigekawa and Yamada, 2012), as having constraints on the amount of leisure time available might in turn constrain the amounts allocated for taking part in activities/consuming items related to leisure time. Whether such goods and services are really dispensable for people out of work has yet to be fully examined (Uzuki, 2012). Long working hours and relatively limited leisure time for Japanese working people are evident. Based on time use data, ${ }^{3}$ Japanese working men on average spend fifty-six hours a week on working and commuting and approximately twenty-six hours on leisure activities, whereas their British counterparts spend spend forty-two hours and and thirty-one and a half hours respectively on these activities.

In the UK, participants who discuss the needs of working-age adults are recruited to include a range of ages across this life stage, from eighteen to sixty-five. The case study that they focus on is aged thirty-two, but there is general agreement within and across groups that people above and below this age might choose to spend their resources in different ways, in particular in terms of social and cultural participation, and that the amounts included provide the ability for individuals to exercise choice. Occasionally, older members of the group may defer to those who are closer in age to the case study individual, but on the whole groups do not find it particularly problematic to discuss the needs of someone who may be not be the same age as them.

However, in Japan the age gap between participants and the case-study individual led to some difficulties (Shigekawa and Yamada, 2012). At the task group stage, where groups first devise the lists of items that are needed, the participants were aged between twenty and fifty. In these groups, where there was a perceived generation gap in opinions, the 
voices of participants who were older than the case-study individual tended to be more influential than those participants who were closer in age to the case-study individual. This is a reflection of cultural differences in Japan, where it is customary to show deference to those older than oneself (see, for example, Giles et al., 2003). In order to counteract this, the checkback and final stage groups were recruited from a narrower age band, and included people between twenty-five and thirty-nine years; however, there is more work to be done to separate the needs common to all generations from those specific to a particular generation.

\section{Budget comparisons}

In the UK, the first MIS budgets were published in 2008 (Bradshaw et al.) and updated annually (Hirsch et al., 2009; Davis et al., 2010, Hirsch, 2011, Davis et al., 2012). In Japan, the budgets for single working-age adults were completed in 2010 and then uprated to the 2011 figures, with budgets for single pensioners being finalised in 2011. This article compares the 2011 figures for the UK and Japan budgets for single working-age people and single pensioners, looking at different dimensions between and within countries. It goes on to compare the MIS for each country with social assistance levels, minimum wage and average earnings.

\section{Comparison of gender and age differences}

In both countries, separate budgets were developed for male and female adults and these were then aggregated to create a non-gender specific budget for pensioners and workingage adults. In the UK, the needs of working-age men and women were initially itemised by single sex groups. There were then two further groups who reviewed and finalised the lists, and these two stages involved mixed groups of men and women. Part of the task of these later groups was to look at areas of difference between the men's and women's budgets to clarify where there were different things needed by each gender, for example in clothing, and identify those budget areas where groups thought that there should be equal provision, for example in terms of money allocated for leisure activities. In Japan, the working-age budgets were entirely devised by single sex groups, so there was not the same opportunity to discuss and possibly amend differences. However, the pensioners' groups were able to perform this task and allowed quite different levels of provision to remain, so it seems unlikely that gender differences between working-age budgets were entirely due to different group composition.

Some patterns were similar in Japan and the United Kingdom. In particular, overall pensioner budgets are significantly lower than working-age budgets. In both countries, older people specified more modest diets, and the nutritionists attached to the project confirmed that this was compatible with good health. Women's clothing budgets were consistently higher than men's, but in Japan the gap was nearly twice as great as in the UK. With Japanese pensioners, the most significant difference was that the budget for gifts was considerably higher for men than women, while that for housing was higher for women than men. This is because men thought it important to be able to give presents to their grandchildren and relatives, while women thought it was important to be able to welcome guests into their home. 


\section{Comparison of MIS totals}

In comparing the total minimum income standard (see Table 1), we exclude rents, as an element that is extremely variable within and between countries, and council tax, which is only applicable in the UK. In comparing the initial results from Japan with the UK, we can make several observations. First, the level of the minimum appears to be broadly similar in the two countries. At exchange rates for November $2011,{ }^{4}(¥ 1=£ 0.0083)$ the MIS excluding rent and council tax for single working-age adults without children was $£ 223.70$ per week in Japan, compared with $£ 184.68$ in the UK. For pensioners, the comparison is $£ 197.63$ (Japan) and $£ 154.62$ (UK). In both cases, the budget for pensioners is a similar proportion of that of the working-age adults ( 84 per cent UK and 88 per cent Japan).

At the start of the research, there was an expectation that health care costs would be higher in Japan than the UK, where the National Health Service provides free primary and secondary healthcare, free prescriptions for pensioners, subsidised dentistry for adults and free contraception through family planning services. This difference was confirmed, but it varied greatly between pensioners and non-pensioners. For working-age adults in Japan, the inclusion of direct health costs and private health insurance comprised 2 per cent of the budget, compared to 1 per cent for health costs in the UK budget (covering the costs of an eye test every two years plus NHS dental costs for six-monthly check ups and one straightforward treatment, for example a filling, each year). For the Japanese pensioners, the health care provision comprised 7 per cent of the budget, compared to 2 per cent of their UK equivalents' budgets. The Japanese figure is very similar to the proportion included for Guernsey in a study conducted in 2011 by the UK MIS team, where private health insurance included by pensioners' groups comprised 6 per cent of the budget (Smith et al., 2011).

\section{Comparison with social assistance and minimum wage}

In 2011, basic out-of-work benefits provided well under half (approximately 40 per cent) of the UK MIS for a single working-age adult, net of rent and council tax. Table 2 shows social assistance levels and the MIS budgets in both Japan and the UK as a weekly amount for working-age singles. Social assistance in this context means livelihood protection (equivalent to livelihood allowance) in Mitaka for Japan, and income support for people out of work for the UK. The comparison shows that Japan's social assistance level of $¥ 19,595$ per week accounts for 74 per cent of the MIS of $¥ 26,395$. When compared with working-age singles in the UK, where the income from social assistance is equivalent to only 40 per cent of the MIS, Japan's social assistance level may seem to be rather generous, although it can be seen that social assistance levels still fall far short of the MIS in both countries. This may appear to be inconsistent with the fact that, in surveys, a large proportion of people in the UK think that social assistance is too high (Clery, 2012). However, as previous research has demonstrated, such views are influenced by respondents', often inaccurate, perceptions of the levels and adequacy of benefits received (Hills, 2001), and by their opinions about what living standard people receiving assistance deserve. The MIS methodology, in contrast, defines an adequate standard of living without asking who 'deserves' it.

For single pensioners in the UK in 2011, state safety-net provision was almost exactly 100 per cent of MIS. However, in this group, the majority may require more than this, 
Table 1 Comparison of MIS budgets between Japan (Mitaka) and the United Kingdom (weekly budgets for single working-age adults and single pensioners)

\begin{tabular}{|c|c|c|c|c|c|c|c|c|}
\hline Category & $\begin{array}{l}\text { Single } \\
\text { working-age } \\
\text { adult } \\
\text { UK }\end{array}$ & $\begin{array}{l}\text { Single } \\
\text { working-age } \\
\text { adult } \\
\text { UK } \\
\text { \% of total } \\
\text { excluding } \\
\text { rent \& and } \\
\text { council tax } \\
2011\end{array}$ & $\begin{array}{l}\text { Single } \\
\text { pensioner } \\
\text { UK }\end{array}$ & $\begin{array}{l}\text { Single pensioner } \\
\text { UK } \\
\text { \% of total } \\
\text { excluding rent } \\
\text { \& council tax } \\
2011\end{array}$ & $\begin{array}{l}\text { Single } \\
\text { working-age } \\
\text { adult } \\
\text { Japan }\end{array}$ & $\begin{array}{l}\text { Single } \\
\text { working-age } \\
\text { adult } \\
\text { Japan } \\
\text { \% of total } \\
\text { excluding } \\
\text { rent } \\
2011\end{array}$ & $\begin{array}{l}\text { Single } \\
\text { pensioner } \\
\text { Japan }\end{array}$ & $\begin{array}{l}\text { Single } \\
\text { pensioner } \\
\text { Japan } \\
\text { \% of total } \\
\text { excluding } \\
\text { rent } \\
2011\end{array}$ \\
\hline Food & 46.31 & 25 & 41.31 & 27 & 9,550 & 35 & 7,343 & 31 \\
\hline Alcohol & 4.96 & 3 & 3.40 & 2 & 488 & 2 & 239 & 1 \\
\hline Tobacco & 0.00 & 0 & 0.00 & 0 & 0 & 0 & 0 & 0 \\
\hline Clothing & 8.56 & 5 & 5.50 & 4 & 2,551 & 9 & 1,305 & 5 \\
\hline Water rates & 5.16 & 3 & 5.16 & 3 & 356 & 1 & 460 & 2 \\
\hline Council tax & 13.95 & 8 & 13.95 & 9 & 0 & 0 & 0 & 0 \\
\hline Household insurances & 2.00 & 1 & 1.80 & 1 & 142 & 1 & 144 & 1 \\
\hline Fuel & 10.51 & 6 & 11.24 & 7 & 1,665 & 6 & 2,186 & 9 \\
\hline Other housing costs & 2.48 & 1 & 3.09 & 2 & 573 & 2 & 288 & 1 \\
\hline Household goods & 10.99 & 6 & 11.17 & 7 & 940 & 3 & 1,268 & 5 \\
\hline Household services & 4.53 & 2 & 5.52 & 4 & 1,594 & 6 & 1,619 & 7 \\
\hline $\begin{array}{l}\text { Personal goods and } \\
\text { services excl. } \\
\text { medical expenses }\end{array}$ & 7.83 & 4 & 8.48 & 5 & 1,368 & 5 & 1,454 & 6 \\
\hline Medical expenses & 1.51 & 1 & 3.43 & 2 & 558 & 2 & 1,778 & 7 \\
\hline Motoring & 0.00 & 0 & 0.00 & 0 & 0 & 0 & 0 & 0 \\
\hline Other travel costs & 22.17 & 12 & 11.24 & 7 & 1,266 & 5 & 208 & 1 \\
\hline $\begin{array}{l}\text { Social and cultural } \\
\text { participation }\end{array}$ & 43.71 & 24 & 29.33 & 19 & 5,900 & 22 & 5,520 & 23 \\
\hline $\begin{array}{l}\text { Headline total - } \\
\text { excluding rent and } \\
\text { childcare }\end{array}$ & 184.68 & 100 & 154.62 & 100 & 26,952 & 100 & 23,811 & 100 \\
\hline
\end{tabular}

Note: Column totals are not always the sum of the rows due to rounding. 
Table 2 MIS compared with social assistance levels in 2011 (a single working-age person)

\begin{tabular}{llll}
\hline \hline & & $\begin{array}{l}\text { Japan (Mitaka) } \\
¥ \text { pw }\end{array}$ & $\begin{array}{l}\text { United Kingdom } \\
\text { £ pw }\end{array}$ \\
\hline MIS & a & 26,395 & 170.72 \\
Social assistance level & b & 19,595 & 67.50 \\
Difference & b-a & $-6,800$ & -103.22 \\
$\begin{array}{l}\text { Benefit income as a } \\
\text { percentage of MIS }\end{array}$ & b/a*100 & 74 & 40 \\
\hline \hline
\end{tabular}

Notes: Excluding rent and UK's MIS excludes council tax. Social assistance refers to livelihood protection for Japan, and out of work income support for the UK.

Source: Hirsch (2011).

Table 3 Gross earnings required to meet MIS in 2011 (a single working-age person)

\begin{tabular}{llll}
\hline \hline & & $\begin{array}{l}\text { Japan (Mitaka) } \\
¥ \text { pw }\end{array}$ & $\begin{array}{l}\text { United Kingdom } \\
£ \text { pw }\end{array}$ \\
\hline MIS & & 43,405 & 240.89 \\
Gross earnings required & & 51,070 & 287.67 \\
Hourly wage rate & $\mathrm{c}$ & 1,362 & 7.67 \\
Minimum wage & $\mathrm{d}$ & 837 & 5.93 \\
Difference & $\mathrm{d}-\mathrm{c}$ & -525 & -1.74 \\
Minimum wage as a & $\mathrm{d} / \mathrm{c}^{*} 100$ & 61 & 77 \\
$\quad \begin{array}{l}\text { percentage of hourly wage } \\
\text { required to meet MIS }\end{array}$ & & & \\
\hline
\end{tabular}

Notes: MIS budgets in this table are the same as those reported in the last row of Table 1. Gross earnings required for Japan is the sum of MIS budget, National Pension contributions, National Health Insurance contributions, income tax and local resident tax, while those for the UK is the sum of MIS budget (including council tax), income tax and National Insurance contributions. Hourly wage rate assumes a 37.5 hour week. UK figures from Hirsch (2011).

because most pensioners in the UK live in houses rather than flats, as assumed for the minimum, and this imposes extra costs such as heating. In Japan, a minimum income guarantee for pensioners providing $¥ 17,770$ per week $^{5}$ constituted 81 per cent of the $¥ 22,033$ needed to reach MIS.

Table 3 shows the level of gross earnings required per week to cover the MIS budget for Japan and the UK for a single working-age person, and translates them into hourly wage rates assuming a 37.5 hour week. They take account of national and local taxes as well as social insurance contributions in both cases. The hourly wages required worked out at $¥ 1,362$ and $£ 7.67$ respectively. The minimum wage in 2011 provided 61 per cent of this amount in Japan (based on the Tokyo minimum wage, $¥ 837$ ) and 79 per cent for the UK (based on the national minimum wage, £5.93). Thus, a single person working full time on the minimum wage would not achieve the MIS standard in either country. However, it is clear that the gap between the required wage rate to meet the MIS and 
the minimum wage rate is greater in Japan than in the UK. Note, however, that this may partly be due to the fact the rent included in the calculation of the MIS budget for Japan is based on the rent of private rental housing, while that for the UK is based on the rent of social housing. In Japan, working-age single people are very unlikely to be eligible for social housing.

The above results suggest that social assistance goes relatively further to meeting MIS requirements for working-age people in Japan than in the UK, whereas minimum wages go relatively further to meeting the requirements in the UK than Japan. This is confirmed if we consider assistance rates relative to average earnings in the two countries. Basic social assistance in Japan is 18 per cent of average wages for a single person, but only 10 per cent in the UK. On the other hand, the minimum wage is 27 per cent of the average wage in Japan but 35 per cent in the UK (based on OECD figures for 2010) (Lee and Jose, 2013). Thus, whether the minimum incomes standard or average wages are used as a benchmark, we find that minimum wages are more generous in the UK but social assistance levels for working-age people are higher in Japan. ${ }^{7}$

\section{Reflections}

There are three main factors that may have created differences in the MIS procedure between Japan and the UK (Uzuki, 2012). The first potential difference is the extent to which the MIS results achieved their intended objective of reflecting a consensus across each group in terms of agreeing what comprises a need for everybody rather than just a preference for individual members. In the course of the UK research, its facilitators have developed a strong expertise in ensuring that particular individuals do not dominate discussion, project their own preferences or mistake 'wants' for 'needs'. Japanese facilitators are only just acquiring this expertise, and in the early stages of research were not always able to avoid this pitfall. For this reason, the early results reported here have to be regarded as to some extent provisional.

In the original UK research, groups were asked at the end of the process if it would be possible to reduce the MIS budgets without falling short of the minimum standard of living. In response to this question, participants in the UK, without exception, insisted that it was impossible to realise the minimum standard of living if they had to remove or reduce the level of provision detailed in the budgets (Bradshaw et al., 2008). In Japan, due to time constraints it was not possible to pose this question, so it is unclear to what extent the Japanese groups' response would differ from that in the UK.

A third difference is that in the UK, when anomalies are detected between the MIS budgets, researchers check the anomalies with participants in group discussions. At the final negotiation stage, both male and female participants from several household types who have joined separate group discussions get together to consider items that show differences between household types for the same gender and items that show differences between men and women from the same type of household, and consider the reasons behind those differences. Furthermore, participants compare the MIS results and expenditure data, look at items that show particularly noticeable differences, discuss reasons for those differences and make modifications as necessary. Participants review the modified minimum cost of living and consider whether they can realise the minimum standard of living with the modified budget (Bradshaw et al., 2008). In Japan, single working-age men and women participated in separate group discussions until the final 
negotiation stage, which meant that there was only a single opportunity for participants to examine the validity of areas that show differences in the cost of living between men and women. Comparison with other consumption data was conducted by the Japanese research team, but not in consultation with the final discussion groups (Shigekawa and Yamada, 2012), and the MIS results are not being modified through this comparison.

In the UK in 2008 (and again in 2012 when this process was conducted for households with children), groups were not inclined to reduce the MIS budgets, even when the amounts allocated exceeded average expenditure for low income groups by a large margin. Groups thought that survey data on what is spent is not necessarily an accurate picture of what is needed, and said that people in constrained financial circumstances were quite likely to be buying less than was needed because of a lack of resources. For example, groups said that when money was short in a household it was much easier to economise on food in order to afford other items, such as fuel. Therefore, the difference between the MIS food budget and the low income expenditure levels was likely to be the result of people going without what they needed to have a healthy and varied diet, and not caused by the MIS budgets being too generous. Thus, it should not necessarily be inferred that if the Japanese groups had had the opportunity to reflect on contrasts between MIS and expenditure levels they would have decreased the budgets.

\section{Impact of regional characteristics}

As found in the UK in the research conducted in urban and rural areas, access to goods and services necessary for the minimum standard of living may be different in rural and urban areas. However, in the UK, it has been found that, across regions, most prices can be standardised to produce a common budget for urban areas (where most people live), with a variation for additional rural needs. UK housing and childcare costs, which cannot be standardised in this way, can be reported separately. In contrast, what was calculated in Japan is the minimum cost of living in Mitaka, Tokyo, and so must be seen as an example of costs in one place rather than a nationally valid figure at this stage. The social assistance and minimum wage rates compared in this study are also only relevant to the region in which Mitaka is situated. The verification of regional effects across various parts of the country remains as a task to be addressed in the future.

\section{Configuration of employment status}

The MIS method is designed to calculate the cost of a minimum socially acceptable standard of living for members of society, regardless of employment status. However, the budgets are developed so as not to preclude anyone from being able to work, so, for example, clothing and shoes suitable for going to job interviews or going out for work are included in the lists of required items. ${ }^{8}$ Although, as suggested by some UK participants in group discussions, people in work may have higher expectations of their own standard of living than people out of work, only the things deemed necessary to all people, regardless of employment status and income, are included in the calculation (Bradshaw et al., 2008).

In Japan, following the UK method, the case studies did not include assumptions about employment status, and took account of things that are necessary for people in work or for people to secure options to work in the calculation of the minimum cost of living. This way of capturing the minimum cost of living is a departure from the conventional (but 
rather covert) conceptualisation of the minimum cost of living embedded in the Japanese system of social assistance (livelihood protection) that only includes the minimum needs for people out of work (Iwanaga, 2011). By diverting from this convention, however, Japanese participants were asked to consider what a 'case study' household needed without specifying their working status, as in the United Kingdom, and it was only when a particular item that might be required only for a working person was discussed that a distinction was made. It is important to emphasise that the MIS budget for a working-age single person thus derived in Japan is appropriate for comparison with the equivalent budget for the UK.

\section{Conclusion}

Although translating a methodology from one context to another poses numerous challenges, it would seem that these are by no means insurmountable. Furthermore, the adoption by a number of countries of the MIS method offers an opportunity to compare minimum living standards requirements as defined by the public in each country, and their relationship to actual incomes, across countries. By 2014, it is expected that five OECD countries, France, Ireland, Japan, Portugal and the United Kingdom, will have data from MIS or a very similar methodology (as well as other countries such as the Netherlands, that have a comparable concept of a minimum standard but differences in method that make data comparisons difficult). Cross-country data comparisons of the countries using a similar method will then be closely examined. Meanwhile the initial results from Japan allow some initial comparisons with the UK, demonstrating both the potential and some of the limitations of such comparison.

\section{Acknowledgements}

The authors would like to thank the editors and reviewers for their constructive and insightful comments. We are also grateful to colleagues Matt Padley and Nicola Lomax at CRSP, Aya Abe at NIPSSR, and Yoko Fukuyama, Rie Shindo, Akemi Ueda, Hiroya Noda, Kiyo Fukai and Ikuko Gomi for their support for the project and the collaborative process.

\section{Notes}

1 However, the Research Committee on a National Minimum never held a meeting after the submission of the interim report on the 23 June 2010.

2 Data sources are: Ministry of Internal Affairs and Communications (2012) 2006 Survey on Time use and Leisure Activities, for Japan and EUROSTAT (2005) Comparable Time Use Statistics - National Tables from 10 European Countries - February 2005 for the UK.

3 Office for National Statistics (2011) 'Labour Market Statistics, December 2011' http://www.ons. gov.uk/ons/rel//ms/labour-market-statistics/december-2011/statistical-bulletin.html (accessed 6 December 2012).

4 www.exchangerates.org.uk/JPY-GBP-28_11_2011-exchange-rate-history.html.

5 This figure is based on the rate of livelihood allowance payable to a person aged seventy and over. The full basic pension of $¥ 15,314$ per week falls below this livelihood allowance rate. Those whose contribution periods for the basic pension are shorter than the full contribution period receive a further lower level.

6 www.oecd.org/employment/employmentpoliciesanddata/onlineoecdemploy mentdatabase.htm. 
7 Note, however, that the take up rate of social assistance is estimated to be low in Japan (Yamada, 2010).

8 However, needs relating to particular jobs (for example, work clothes for manual workers and nurses' uniforms) are not regarded as the minimum necessary things for everyone.

\section{References}

Bradshaw, J., Middleton, S., Davis, A., Oldfield, N., Smith, N., Cusworth, L. and Williams, J. (2008) A Minimum Income Standard for Britain: What People Think, York: Joseph Rowntree Foundation.

Clery, E. (2012) 'Are tough times affecting attitudes to welfare?', in A. Park, E. Clery, J. Curtice, M. Phillips and D. Utting (eds.), British Social Attitudes: The 29th Report, London: NatCen Social Research, www.bsa-29.natcen.ac.uk.

Davis, A., Hirsch, D. and Smith, N. (2010) A Minimum Income Standard for the UK in 2010, York: Joseph Rowntree Foundation.

Davis, A., Hirsch, D., Smith, N., Beckhelling, J. and Padley, M. (2012) A Minimum Income Standard for the UK in 2012: Keeping up in hard times, York: Joseph Rowntree Foundation.

Eurostat (2005) Comparable Time Use Statistics - National Tables from 10 European Countries February 2005, Luxembourg: Office for Official Publications of the European Communities, http://epp.eurostat.ec.europa.eu/cache/ITY_OFFPUB/KS-CC-05-001/EN/KS-CC-05-001-EN.PDF.

Giles, H., Noels, K. A., Williams, A., Ota, H., Lim, T.-S., Sik, H. N., Ryan, E. B. and Somera, L. (2003) 'Intergenerational communication across cultures: young people's perceptions of conversations with family elders, non-family elders and same-age peers', Journal of Cross-Cultural Gerontology, 18, 1, $1-32$.

Hills, J. (2001) 'Poverty and social security: what rights? Whose responsibilities?', in A. Park, J. Curtice, K. Thomson, L. Jarvis and C. Bromley (eds.), British Social Attitudes: The 18th Report-Public Policy, Social Ties, London: Sage.

Hirsch, D. (1993) City Strategies for Lifelong Learning, Paris: OECD/Centre for Educational Research and Innovation.

Hirsch, D. (2011) A Minimum Income Standard for the UK in 2011, York: Joseph Rowntree Foundation.

Hirsch, D., Davis, A. and Smith, N. (2009) A Minimum Income Standard for Britain in 2009, York: Joseph Rowntree Foundation.

Iwanaga, R. (2011) How the Japanese Public Assistance System Formulated the Concept of Minimum Living Standards: Historical Analysis of the Standards and Implementation Guidelines, Kyoto: Minerva Shobo (in Japanese).

Iwanaga, R. and Iwata, M. (2012) 'Introduction to the special issue of a minimum income standard research in Japan', Social Policy and Labor Studies, 4, 1, 58-60 (in Japanese).

Lee, O. and Jose, T. (2013) 'How might recent UK education policy changes affect the supply of skills to the labour market? Are these changes desirable?', Norwich Economic Papers, 8 (May), www.oecd.org/employment/employmentpoliciesanddata/onlineoecdemploy mentdatabase.htm.

Middleton, S. (1997) Household Budgetary Requirements in Jersey, CRSP296, Loughborough: Centre for Research in Social Policy.

Middleton, S. (2000) 'Agreeing poverty lines: the development of consensual budget standards methodology', in J. Bradshaw and R. Sainsbury (eds.), Researching Poverty, Aldershot: Ashgate, pp. 59-76.

Middleton, S., Ashworth, K. and Walker, R. (1994) Family Fortunes: Pressures on Parents and Children in the 1990s, London: CPAG Ltd.

Ministry of Internal Affairs and Communications (2012) Labour Force Survey, www.stat.go.jp/ data/nenkan/pdf/yhyou16.pdf (accessed 6 December 2012).

Nibud (2010) The Minimum Agreed Upon - Consensual Budget Standards for the Netherlands, The Hague: Nibud. 
Ogawa, A. (2009) 'Japan's new lifelong learning policy: exploring lessons from the European knowledge economy', International Journal of Lifelong Education, 28, 5, 601-14, http://dx.doi.org/ 10.1080/02601370903190011 (accessed 25 October 2012).

Parker, H. (ed.) (1995) Modest but Adequate: Summary Budgets for Sixteen Households, October 1994 Prices, London: FBU, NCC Publications.

Parker, H. (ed.) (1998) Low Cost but Acceptable: A Minimum Income Standard for the UK - Families with Young Children, Bristol: The Policy Press.

Shigekawa, J. and Yamada, A. (2012) 'Measuring minimum income standards in Japan: applying the new British method', Social Policy and Labor Studies, 4, 1, 71-84 (in Japanese).

Smith, N., Phung, V., Davis, A. and Hirsch, D. (2009) A Minimum Income Standard for Northern Ireland, York: Joseph Rowntree Foundation.

Smith, N., Davis, A. and Hirsch, D. (2010) A Minimum Income Standard for Rural Households, York: Joseph Rowntree Foundation and Commission for Rural Communities.

Smith, N., Davis, A. and Hirsch, D. (2011) A Minimum Income Standard for Guernsey, CRSP 618, Loughborough: Centre for Research in Social Policy.

Uzuki, Y. (2012) 'Comparing minimum income standards between Japan and the UK: MIS budgets and their implications', Social Policy and Labor Studies, 4, 1, 85-96 (in Japanese).

Walker, R. (1987) 'Consensual approaches to the definition of poverty: towards an alternative methodology', Journal of Social Policy, 16, 2, 213-26.

Yamada, A. (2010) 'Targeting the relative benefit levels of social assistance to minimum wages in an international perspective', Social Policy and Labor Studies, 2, 2, 33-47 (in Japanese). 